\title{
PERANCANGAN APLIKASI PENGENALAN PAHLAWAN INDONESIA BERBASIS ANDROID
}

\author{
Ardi Tri Wibowo ${ }^{1}$, Forkas Tiroy Santos Butar-butar ${ }^{2}$, Nur Ali $^{3}$ \\ Program Studi Teknik Informatika, Fakultas Teknik dan Ilmu Komputer, \\ Universitas Indraprasta PGRI \\ Jalan Raya Tengah No 80, Kelurahan Gedong, Pasar Rebo, Jakarta Timur \\ Arditriwibowo96@gmail.com¹, Fortysant.bb@gmail.com², Nurali1901@gmail.com³
}

\begin{abstract}
Abstrak
Aplikasi pembelajaran adalah media yang dapat digunakan untuk menyampaikan isi materi yang melibatkan perangkat bergerak seperti ponsel berbasis android. Seiring dengan perkembangan teknologi informasi, saat ini sudah banyak device yang di ciptakan untuk mempermudah mengakses informasi. Sistem informasi tentang sejarah pahlawan Indonesia saat ini masih banyak di dominasi oleh buku. Namun dalam ranah pembelajaran Sejarah, Sejarah tidak mungkin di kemukakan secara objektif (Setianto, 2012). Oleh karna itu akan dibuat suatu aplikasi pembelajaran yang memanfaatkan perkembangan teknologi berbasis mobile Android yang berkembang pesat saat ini. Tujuan dari pembuatan aplikasi pengenalan pahlawan Indonesia adalah untuk dapat mengenal pahlawan Indonesia serta dapat memberikan informasi kepada masyarakat mengenai pentingnya mengenal pahlawan Indonesia untuk menumbuhkan rasa nasionalisme. Penggunaan game berbasis Android pada smartphone semakin banyak sehingga tidak dapat di pungkiri anak anak semakin betah berlama-lama bermain game Android dismartphonenya, hal ini menjadi problem tersendiri bagi proses pembelajaran anak anak (Nugroho \& Komarudin, 2018). Metode penelitian yang digunakan dalam penelitian ini adalah metode penelitian dan pengembangan atau dikenal juga dengan metode R\&D (Research and Development), yaitu metode penelitian yang digunakan untuk menghasilkan produk tertentu dan menguji keefektifan produk tersebut. Setelah dilakukan penelitian serta pembuatan aplikasi pengenalan pahlawan Indonesia, dapat disimpulkan aplikasi pengenalan pahlawan Indonesia ini dapat digunakan dengan mudah oleh user karena di desain dengan desain yang mudah dimengerti oleh user serta dapat memberikan kemudahan dalam mengakses informasi mengenai pahlawan nasional Indonesia.
\end{abstract}

Kata Kunci: Perancangan, Pengenalan Pahlawan, Android

\begin{abstract}
Learning applications are media that can be used to convey material content that involves mobile devices such as Android-based phones. Along with the development of information technology, nowadays many devices have been created to make it easier to access information. Many books dominate the information system about the history of Indonesia's heroes. However, in the realm of history learning, history cannot be presented objectively (Setianto, 2012). Therefore, a learning application will be made that takes advantage of the development of mobile android-based technology which is growing rapidly at this time. The purpose of making an application to introduce Indonesian heroes is to be able to get to know Indonesian heroes and to be able to provide information to the public about the importance of knowing Indonesian heroes to foster a sense of nationalism. The use of Android-based games on smartphones is increasing so it cannot be denied that children are increasingly comfortable playing Android games on their smartphones, this is a problem in itself for the learning process of children (Nugroho \& Komarudin, 2018). The research method used in this research is the research and development method or also known as the $R \& D$ (Research and Development) method, which is a research method used to produce certain products and test the effectiveness of these products. After conducting research and making an application for the introduction of Indonesian heroes, it can be concluded that this application of introduction to Indonesian heroes can be used easily by the user because it is designed with a design that is easy for the user to understand and can provide easy access to information about Indonesia's national heroes.
\end{abstract}

Keywords: Planning, Hero Introduction, Android 


\section{PENDAHULUAN}

Pahlawan nasional adalah gelar yang diberikan kepada warga negara Indonesia atau seseorang yang berjuang melawan penjajahan di wilayah yang sekarang menjadi wilayah Negara Kesatuan Republik Indonesia (NKRI) yang gugur atau meninggal dunia demi membela bangsa dan Negara. Atau pahlawan merujuk kepada diri seseorang karena keberanian, kekuatan, pengorbanan dan kemampuan untuk mengatasi masalah. (Azri\&Agung, 2017). Seiring dengan berkembangnya teknologi informasi, saat ini sudah banyak device yang diciptakan untuk mempermudah dalam mengakses informasi. Sistem informasi tentang sejarah para pahlawan indonesia saat ini masih banyak di dominasi buku. Oleh karena itu akan dibuat suatu aplikasi pembelajaran yang memanfaatkan perkembangan teknologi berbasis mobile android yang berkembang pesat saat ini. Android merupakan sistem operasi untuk telepon seluler yang berbasis Linux. Android menyediakan platform terbuka bagi para pengembang untuk menciptakan aplikasi mereka sendiri untuk digunakan oleh bermacam peranti bergerak. Android umum digunakan di smartphone dan juga tablet PC. Fungsinya sama seperti sistem operasi Symbian di Nokia, iOS di Apple dan BlackBerry OS (Nazruddin Safaat H, 2012). Aplikasi ini akan membahas tentang materi sejarah dan biografi. Untuk menanggulangi masalah diatas maka pembuatan aplikasi yang berbasis android pilihan yang tepat karena dengan metode pembelajaran secara audio visual (multimedia) seseorang dapat belajar secara mandiri baik di rumah atau di manapun. Tujuan dari penelitian dan pembuatan aplikasi pengenalan pahlawan Indonesia berbasis android dalam penelitian ini adalah Menghasilkan aplikasi berbasis android yang user friendly dalam memahami perjuangan pahlawan indonesia. Pengertian pahlawan adalah seseorang yang berbakti kepada masyarakat, negara, bangsa dan atau umat manusia tanpa menyerah dalam mencapai cita-citanya yang mulia, sehingga rela berkorban demi tercapainya tujuan, dengan dilandasi oleh sikap tanpa pamrih pribadi. Seorang pahlawan bangsa yang dengan sepenuh hati mencintai negara bangsanya sehingga rela berkorban demi kelestarian dan kejayaan bangsa negaranya disebut juga sebagai patriot. Kategori pahlawan pun ada banyak, tergantung dengan prestasi yang disumbangkannya, seperti pahlawan kemanusiaan, pahlawan nasional, pahlawan perintis kemerdekaan, pahlawan revolusi, pahlawan proklamasi, pahlawan iman, pahlawan tanpa tanda jasa, pahlawan kesiangan, dan sebagainya (Budiman\&Ariani, 2014). Sedangkan pengertian Aplikasi adalah suatu unit perangkat lunak yang dibuat untuk melayani kebutuhan akan beberapa aktivitas seperti system perniagaan, game, pelayanan masyarakat, periklanan, atau semua proses yang hampir manusia (Pramana, 2012).

\section{PENELITIAN RELEVAN}

Peneliti pertama dalam jurnal yang disusun oleh Achmad Fauzi yang berjudul Aplikasi Pengenalan Cabang Olahraga Berbasis Android Jakarta dengan menggunakan metode R\&D (Research and Development). Menjelaskan bahwa dalam struktur navigasi pembuatan aplikasi tersusun dengan sistimatis dan mudah. Struktur navigasi yang digunakan untuk pembuatan aplikasi pengenalan ragam cabang olahraga ini adalah navigasi campuran (Fauzi, 2020).

Penelitian yang kedua dalam jurnal yang disusun oleh Rusli Wanasuria yang berjudul Aplikasi Pengenalan Anatomi Tubuh Manusia Berbasis Android Jakarta dengan menggunakan metode prototype,menjelaskan metode prototype suatu metode dalam pengembangan sistem yang menggunakan pendekatan untuk membuat suatu program dengan cepat dan bertahap sehingga segera dapat dievaluasi oleh pemakai. Sedangkan metode yang peneliti buat menggunakan metode R\&D (Research and Development), yaitu metode penelitian yang digunakan untuk menghasilkan produk tertentu dan menguji keefektifan produk teresebut (Wanasuria et al., 2020).

\section{METODE PENELITIAN}

Metode penelitian yang digunakan dalam penelitian ini adalah metode penelitian dan pengembangan atau dikenal juga dengan metode $\mathrm{R} \& \mathrm{D}$ (Research and Development) yaitu metode penelitian digunakan untuk menghasilkan produk tertentu dan menguji keefektifan produk 
tersebut.(Sugiyono, 2016). Dalam rangka menyusun penelitian ini, peneliti berusaha sedapat mungkin mendapatkan data yang cukup dengan cara pengumpulan bahan-bahan Keterangan data yang berhubungan dengan judul penelitian ini, sehingga tidak menyimpang dari pokok permasalahan. Dalam penelitian, adapaun langkah-langkah yang dilakukan untuk mengembangkan sistem dalam penyusunan ini adalah metode dalam pengumpulan data. Pengumpulan data dari situs-situs internet, dari kutipan buku, dan dari hasil laporan lain yang berkaitan dengan android. Selanjutnya melakukan pengamatan dengan cara bertanya pada forum online terhadap suatu permasalahan yang bertujuan untuk mengamati dan membedah pengkodean dari contoh-contoh android yang telah ada sehingga di peroleh data-data yang bisa digunakan dalam pengkodean. Kemudian dirancanglah dan diimplementasikan aplikasi pengenalan pahlawan Indonesia yang dikembangkan memakai android studio dan bahasa pemogrman java. Selanjutnya pengujian terhadap sistem tersebut dilakukan sampai semua tahap selesai. Dan dengan pemeliharaan sistem yang telah siap di aplikasikan.

\section{HASIL DAN PEMBAHASAN}

Berdasarkan analisa peneliti untuk pengenalan pahlawan yang berbasis android ini sangat membantu untuk menambah wawasan kita terutama anak sekolah dasar untuk mengenal pahawanpahlawan Indonesia dan sangat memudahkan pengguna untuk mengetehui pahlawan-pahlawan yang ada di Indonesia beserta sejarah perang yang pernah terjadi di Indonesia kapan pun mereka mau tanpa harus membuka buku ataupun menjelajah situs internet karna aplikasi yang peneliti buat ini tidak memerlukan internet atau offline. Berikut Flowchart aplikasi pengenalan pahlawan Indonesia dapat di gambarkan sebagai berikut :

\section{Tampilan Flowchart Splashscreen}

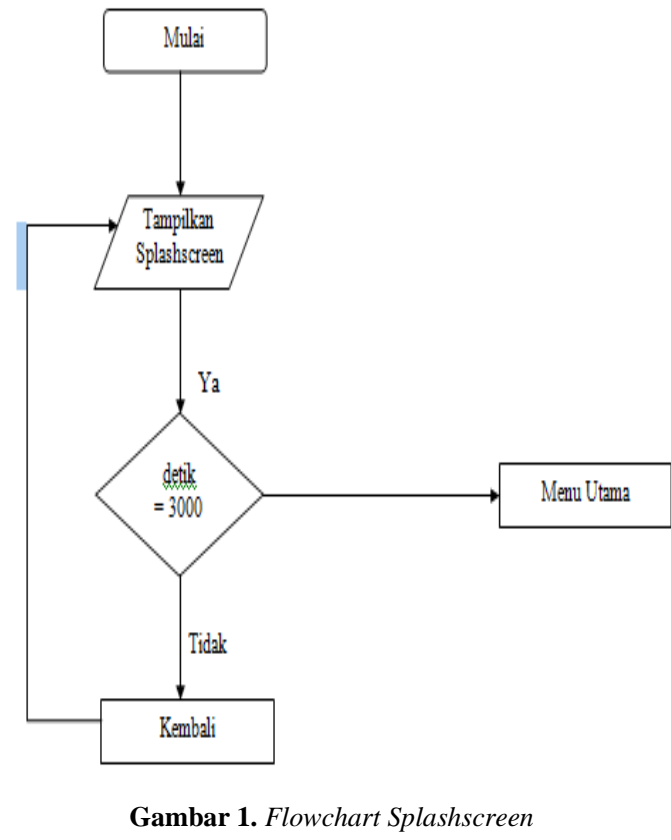

Gambar diatas merupakan flowchart splashscreen yang akan digunakan pada aplikasi, spalshscreen muncul pada saat aplikasi pertama kali dijalankan. 


\section{Tampilan Flowchart Menu Utama}

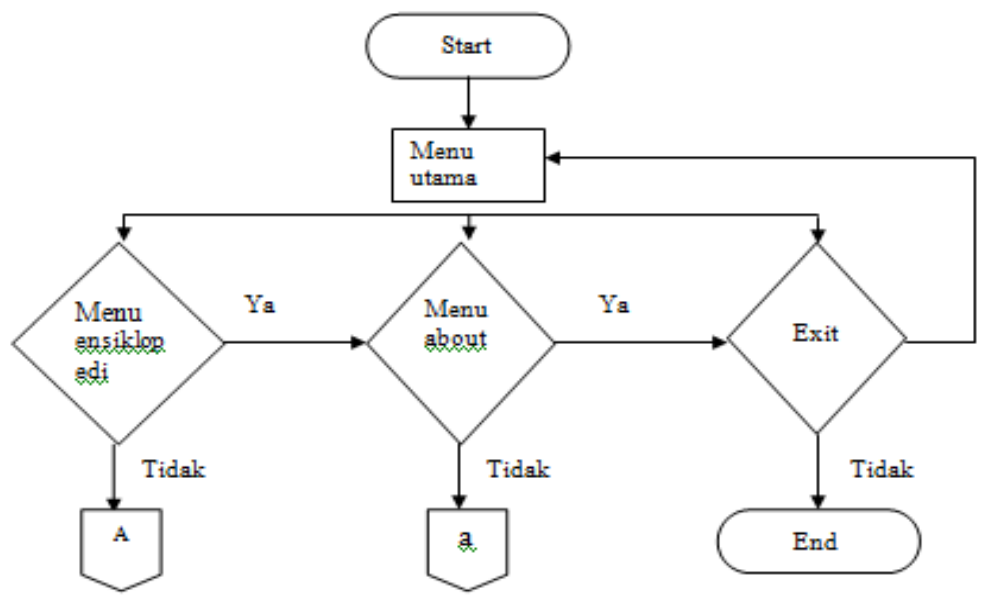

Gambar 2. Flowchart Menu Utama

Gambar diatas merupakan flowchart menu utama, pada menu utama terdapat beberapa menu pilihan lainnya.

\section{Tampilan Use Case diagram}

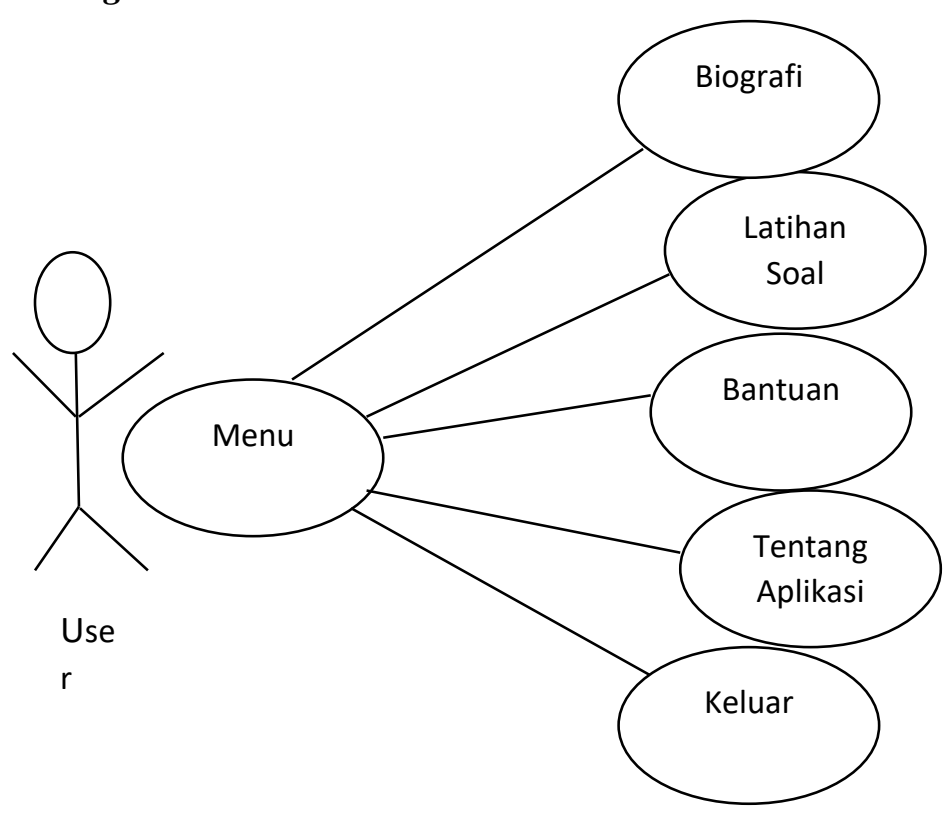

Gambar 3. Flowchart Use Case Diagram

Activity diagram menggambarkan aliran kerja atau aktivitas dari sebuah sistem atau proses bisnis atau menggambarkan aktivitas sistem bukan apa yang dilakukan aktor, jadi aktivitas yang dapat dilakukan oleh sistem.(Rosa \& Salahuddin, 2013) 


\section{Tampilan Aplikasi}

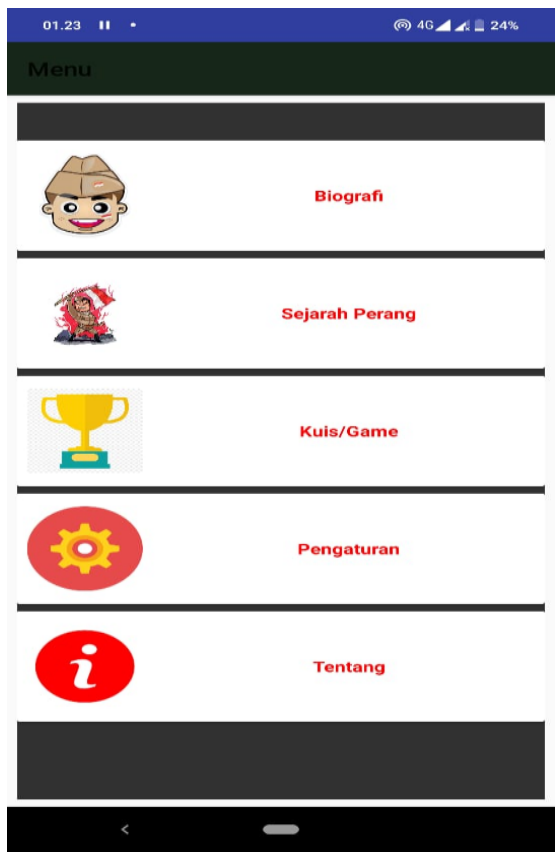

Gambar 4. Tampilan Login

Gambar diatas merupakan tampilan menu utama yang menampilkan beberapa pilihan menu yang tersedia sesuai keinginan user.

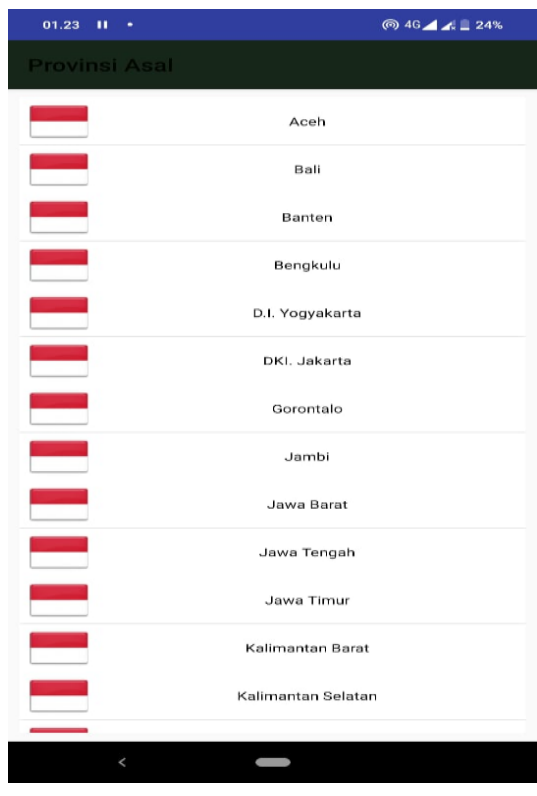

Gambar 5. Tampilan Nama Provinsi

Tampilan nama provinsi, menampilkan nama-nama provinsi yang ada di Indonesia. tamplian nama provinsi dibuat untuk memudahkan user untuk memilih provinsi mana yang ingin diketehui lebih detail mengenai pahlawan sesuai asal provinsi yang dipilih. 


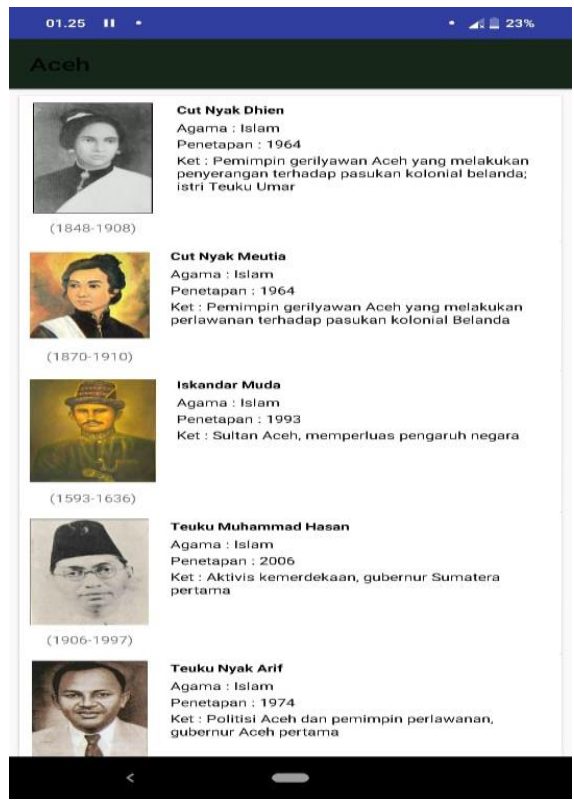

Gambar 6. Tampilan Biografi

Tampilan biografi pahlawan, menampilkan nama-nama dan foto pahlawan jika user ingin mengetahui lebih detail biografi pahlawan yang di inginkan user hanya mengklik foto pahlawan yang di inginkan, setelah user klik foto pahlawan, penjelasan yang lebih detail akan tersedia.

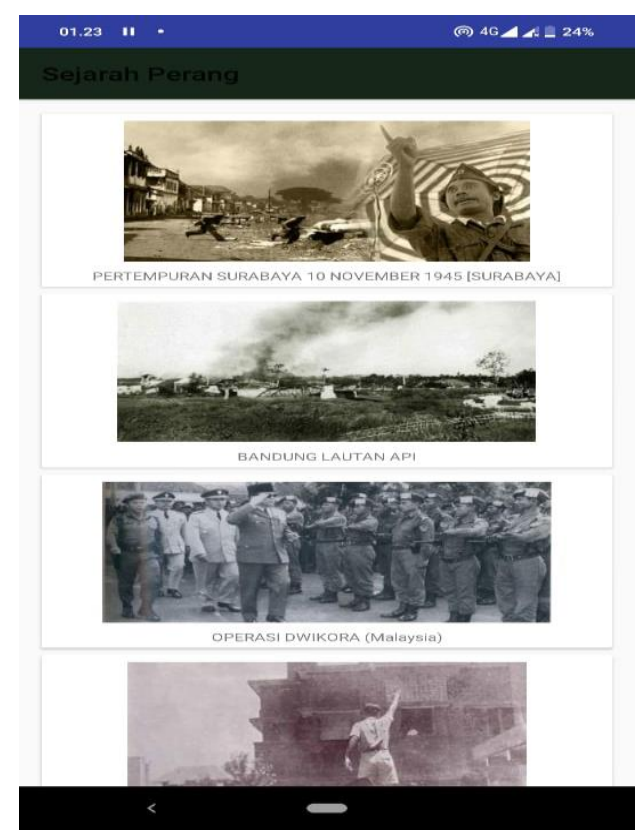

Gambar 7. Tampilan Sejarah Perang

Tampilan sejarah perang terdapat nama-nama sejarah perang yang pernah terjadi di Indonesia. Jika user ingin mengetahui sejarah perang secara detail user hanya mengklik gambar salah satu sejarah perang, maka penjelsan yang detail akan tampil. 


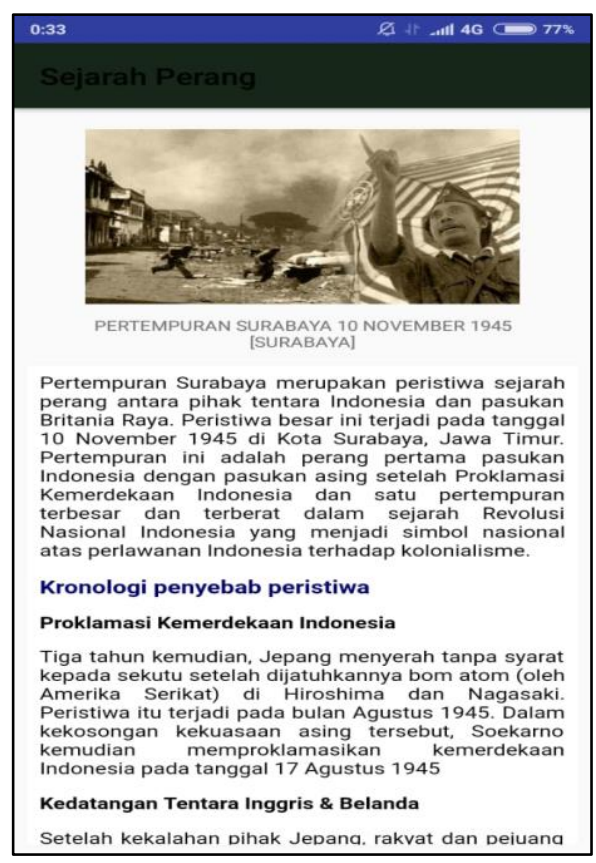

Gambar 8. Tampilan Penjelasan Sejarah Perang

Tampilan penjelasan sejarah perang, menampilkan nama dan foto serta penjelasan sejarah perang yang pernah terjadi di Indonesia secara detail.

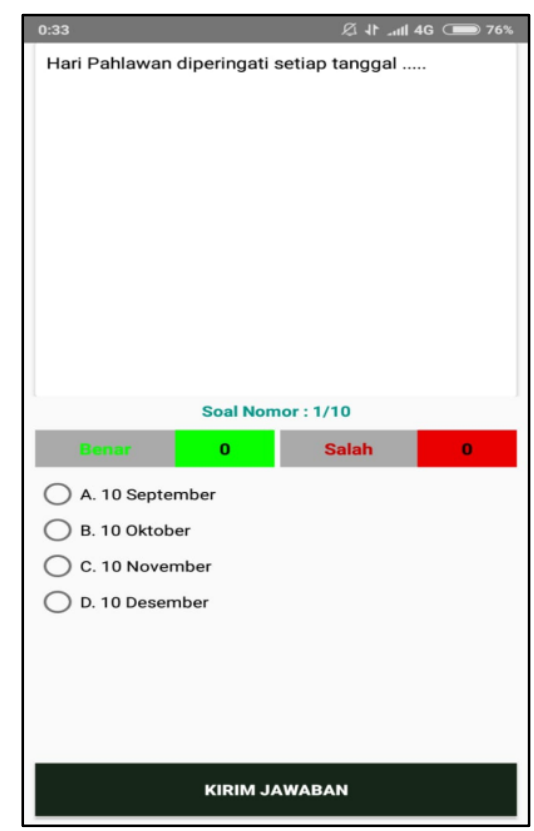

Gambar 9. Tampilan Kuis Pilihan Ganda

Pada tampilan kuis pilihan ganda terdapat pertanyaan mengenai pahlawan dan empat jawaban kemudian user harus memilih dari salah satu jawaban yang benar. 


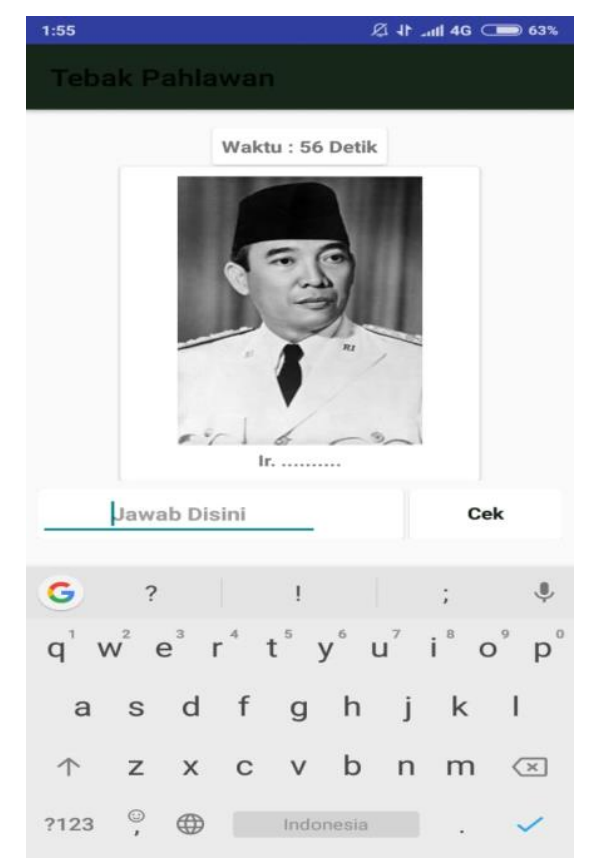

Gambar 10. Tampilan Kuis Tebak Pahlawan.

Pada tampilan kuis tebak pahlawan user di tampilkan dengan foto wajah pahlawan dan user diharuskan menjawab dengan benar jika jawaban user tidak tepat maka user tidak akan bisa melanjutkan ke level berikutnya.

\section{SIMPULAN}

Berdasarkan uraian dan analisis yang telah dilakukan pada bab-bab sebelummnya, maka dapat ditarik kesimpulan yaitu aplikasi pengenalan pahlawan yang berjalan saat ini sudah memenuhi kategori cukup, sehingga sudah dapat menyajikan informasi yang sesuai, aplikasi ini pun dapat menyelesaikan masalah sistem informasi dengan baik dan mampu memberikan tingkat akurasi sistem dalam pengenalan nama-nama pahlawan. Tanggapan responden mengenai aplikasi pengengenalan pahlawan dalam kategori cukup. Karena sudah dapat menyajikan informasi yang sesuai dan mempermudah dalam penggunaannya sudah cukup dirasakan oleh pengguna.

\section{DAFTAR PUSTAKA}

Azri, B. Y., \& Agung, I. M. (2017). PAHLAWAN: Siapa mereka? Pendekatan psikologi indigenous. Jurnal Psikologi Sosial. https://doi.org/10.7454/jps.2017.9

Budiman, A., \& Ariani, D. (2014). Aplikasi Interaktif Pengenalan Pahlawan Revolusi Indonesia Berbasis Multimedia. Jurnal Sisfotek Global.

Fauzi, A. (2020). Aplikasi Pengenalan Ragam Cabang Olahraga Berbasis Android. Jurnal Riset Dan Aplikasi Mahasiswa Informatika (JRAMI). https://doi.org/10.30998/jrami.v1i01.171

Nazruddin Safaat H. (2012). Android: Pemrograman Aplikasi Mobile Smartphone dan Tablet PC Berbasis Android (Edisi Revisi). In Android.

Nugroho, A. H., \& Komarudin, R. (2018). Pengembangan Game Puzzle Berbasis Android sebagai Media Edukasi Pengenalan Pahlawan Nasional. Informatics For Educators and Professionals.

Pramana, H. W. (2012). Aplikasi Inventory Berbasis Access 2003. Jakarta: PT. Elex Media Komputindo.

Rosa \& Salahuddin, 2013. (2013). UML, Use Case Diagram, Activity Diagram, Class Diagram. In Rekayasa Perangkat Lunak Terstruktur.

Setianto, Y. (2012). Dikotomi Bebas Nilai dan Nilai Pendidikan dalam Pembelajaran Sejarah. Jurnal Pendidikan Dan Kebudayaan. https://doi.org/10.24832/jpnk.v18i4.103

Sugiyono. (2016). Metode Penelitian dan Pengembangan (Research and Development/R\&D). Bandung: Alfabeta.

Wanasuria, R., Ismawan, F., \& Heriyati, H. (2020). Aplikasi Pengenalan Anatomi Tubuh Manusia Berbasis Android. Jurnal Riset Dan Aplikasi Mahasiswa Informatika (JRAMI). https://doi.org/10.30998/jrami.v1i01.185 